\title{
PERBANDINGAN MODEL PEMBELAJARAN THINK TALK WRITE \\ (TTW) DENGAN MODEL PEMBELAJARAN SCRAMBLE \\ TERHADAP KETERAMPILAN MENULIS TEKS \\ EKSPLANASI SISWA KELAS XI SMA N I GUNUNG TULEH
}

\author{
Lola Safitri, Afrini Rahmi, Indriani Nisja \\ Program Studi Pendidikan Bahasa dan Sastra Indonesia STKIP PGRI Sumatera Barat \\ safitrilola6@gmail.com
}

\begin{abstract}
This research is motivated by the problem of students not being skilled in writing explanatory text. This study aims to describe the Comparison of Think Talk Write (TTW) Learning with Scramble Explanatory Text Skills of Class XI Students of SMA N I Gunung Tuleh. This type of quantitative research with experimental. The research sample was 50 students of class XI SMAN I Gunung Tuleh consisting of 24 students/experiment I and 26 students/experiment II. The data of this study were the scores of explanatory text writing skills using the Think Talk Write (TTW) Scramble model of class XI students of SMA N I GunungTuleh. The risearch results can be sumarized as follows. First, the explanatory text writing skills of class XI SMA N I Gunung Tuleh with the Think Talk Write (TTW) model obtained an average of 63.33 in the range of 56-65\% with sufficient qualifications (C). Second, the students' explanatory text writing skills ofclass XI SMA N I Gunung Tuleh with the Scramble model obtained an average of 70.76 in the range with the qualification More than Enough (LdC). Third, based on the t-test of the hypothesis tcount>ttable (2.33>1.67). So it can be concluded that the use of the Scramble model is better used to improve the explanatory text writing skills of class XI students of SMA N I Gunung Tuleh. Third, based results of the t-test there is a comparison of the use (TTW) with the Scramble model on the explanatory text writing skills of class XI SMA N I Gunung Tuleh because tcount $>$ ttable $(2.33>1.67)$. So, it can be concluded that the use of the Scramble model is better used to improve the explanatory text writing skills of class XI SMA N I Gunung Tuleh.
\end{abstract}

Keywords: Think Talk Write (TTW), Scramble, Explanation Text.

\section{PENDAHULUAN}

Pada kurikulum

pembelajaran

bahasa

merupakan berperan

2013

mengembangkan

penting

untuk

donesia

keterampilan

yang serta meningkatkan

siswa ketika 
menggunakan bahasa Indonesia baik bentuk tulis ataupun lisan/berbasis teks.

Teks adalah ungkapan lengkap pemikiran manusia. Teks dalam bahasa Indonesia memiliki makna, pikiran, ide seseorang yang dituangkan kedalam bentuk tulisan.

Sesuai dengan pernyataan Dalman (2015:3), kegiatan komunikasi berupa penyampaian pesan atau informasi secara tertulis kepada pihaklain menggunakan bahasa tulis sebagai alat medianya. Dengan keterampilan menulis, siswa dapat menggungkapkan perasaan mengekspresikan gagasan. Siswa harus menguasai keterampilan menulis teks eksplanasi (fenomena alam, sosial, serta ilmu pengetahuan alam), menjelaskan logika dengan peristiwa/peristiwa-peristiwa sederhana yang terjadi disekitar manusia. Mulyadi (2016:239). Menyatakan bahwa teks eksplanasi adalah teks yang menceritakan proses terjadinya sesuatu. Dengan adanya teks tersebut, kita dapat memperoleh gambaran tentang latarbelakang terjadinya sesuatu secara jelas dan logis. Teks eksplanasi menggunakan fakta dan pernyataan yang memiliki hubungan kausalitas (sebab-akibat).
Menulis teks eksplanasi diajarkan pada tingkat SMAN kelas XI dengan KI3, yaitu memahami, menerapkan, dan menganalisis pengetahuan faktual, konseptual, procedural, dan metakognitif berdasarkan rasa ingin tahunya tentang ilmu pengetahuan, teknologi, pengetahuan, teknologi, seni, budaya, dan human dengan wawasan kemanusiaan, kebangsaan, kenegaraan, dan peradaban terkait penyebab fenomena dan kejadian sertamenerapkan pengetahuan prosedural pada bidang kajian yang spesifik sesuai dengan bakat dan minatnya untuk memecahkan masalah. KD 4.3 mengkontruksi informasi (pengetahuan dan urutan kejadian) dalam teks eksplanasi secara lisandan tulisan.

Hasil wawancara bersama Yasri, S.Pd. guru XI SMA N I Gunung Tuleh, pada tanggal 07 Maret 2020 terdapat permasalah,masih banyaknyasiswa belum paham dengan teks eksplanasi terutama dari segi ciriciri kebahasaan teks eksplanasi. Selain wawancara dengan guru kemudian, wawancarai siswa XI SMA N I Gunung Tuleh. Dapat disimpulkan bahwa permasalahan, rendah 
pemahamannya tentang materi teks eksplanasi. Melalui modelini eksplanasi, struktur, ciri-ciri membantu untuk lebih meningkatkan kebahasaan teks eksplanasi. lagi keterampilan mereka dalam

Dari permasalahan diatas, maka pelajaran menulis, karena model ini beberapa tindakan membantu siswa sama-sama menerapkan model yaitu menggunakan (TTW). pembelajaran secara kelompok, Mengembangkan ide-ide/ gagasan- sehingga nantinya akan dapat gagasan serta pendapatnya, karena meningkatkan semangat siswa dalam dalam model pembelajaran TTW belajar teks eksplanasi.

siswa secara bersama-sama disuruh berpikir, berdiskusi, dan menuliskan tentang suatu fenomena atau peristiwa alam, sosial yang terjadi dilingkungan sekitar.

Sohimin (2016:212), menjelaskan model (TTW) merupakan suatu model pembelajaran untuk melatih keterampilan peserta didik dalam menulis. Selain TTW dapat digunakan untuk membantu meningkat

\section{METODE PENELITIAN}

Jenis penelitian kuantitatif. Sugiyono (2014:23), dilakukan meneliti populasi atau sampel. Data di kumpulkan menggunakan instrumen penelitian, metode eksperimen (quasi). Populasi penelitian, XI 2020/2021, berjumlah 160 orang pada 6 kelas, yaitu kelas XI IPS1-4 danIPA12.Pemilihan pengambilan sampel keterampilan menulis teks eksplanasi siswa yaitu model pembelajaran dilakukan dengan purpose sampling, sampelnya XI IPS3 dan IPS4 SMA N I Scramble. Huda (2014:303), Gunung Tuleh yang berjumlah menjelaskan Scramble merupakan metode pembelajaran yang 50/orang. Instrumen penelitian tes meningkatkan konsentrasi serta kecepatan berpikir siswa.

Melalui penggunaan model unjuk kerja.Teknik pengumpulan data pada penelitian dilakukan 4 tahap, duakali/I, duakali/II.

pembelajaran TTW dan Scramble I duakali/pertemuan menggunakan (kooperatif) dapat membantu dan model (TTW) sebagai berikut, Pertama, mempermudah siswa dalam menulis guru membagikan LKS tentang teks 
eksplanasi, dan diarahkan oleh guru. Kedua, Guru meminta peserta menulis masalah yang ditemukanada diLKS membuatkan catatan kecil (intisari) secara individu tentang apa yang iaketahui/tidak. Setelah hal itu, peserta didik menyelesaikan masalah individu, dan menyatukanlah ide kemudian diterjemahkan kebahasa sendiri. Ketiga, Guru membagi siswa menjadi berkelompok (3-5siswa). Keempat, Siswa berdiskusi dan membahas isi dari catatan kecil yang mereka peroleh. Kemudian siswa menyampaikan isi catatan kecil tersebut dengan bahasanya sendiri. Serta siswa membahas tentang struktur dan kebahasaan pada teks eksplanasi yang akan ditulis. Pada tahapan inilah akan terjadi proses berbicara (talk). Kelima, Setelah siswa menjawab soal yang telah diberikan, guru memerintah untuk menulis teks eksplanasi dengan tema "Bencana Alam" sesuai dengan struktur dan kaidah kebahasaan teks eksplanasi. Keenam, menyajikan hasil diskusi dan kelompok lainnya memberi tanggapan. Ketujuh, penilaian dan kesimpulan.

Pada pertemuan-kedua di kelas eksperimen I, diberikan tes berupa unjuk kerja menuliskan teks eksplanasi dengan tema "Permasalahan Sosial", lalu lembaran kerja siswa dikumpulkan dan diperiksa sesuai dengan indikator yang dinilai.

Tahap kedua dilakukan di kelas eksperimen II. Pertemuan pertama, pengumpulan data mengunakan model eksperimen pembelajaran Scramble dengan langkah-langkah sebagai berikut: Pertama, 1) Pertama-tama guru menyiapkan bahan serta contoh teks eksplanasi dengan tema "Bencana Alam" sebagai contoh untuk dibaca oleh siswa. Selanjutnya media kartu soal dan kartu jawab yang telah diacak cara penulisannya. 2) Setelah kelompok dibagi, guru mengatur tempat duduk siswa kelompok membagikan soal. 3) Tahap terakhir dari tahap ini. Guru menanyakan kesiapan siswa saat belajar misalnya menanyakan kepada kelompok apakah sudah mendapatkan kartu soal dan contoh teks eksplanasi.

Kedua, 1) Berdiskusi dan mencari kartu soal serta jawaban yang cocok dari perintah soal dan menuliskan mana jawaban yang benar lalu menuliskan teks eksplanasi dilembar yang sudah disediakan oleh guru masing-masing 
kelompok. 2) Setelah selesai bekerja kelompok. Guru menunjuk satu perwakilan kelompok mempresentasikan hasil dari kerja kelompok kecilnya, dan mempertanggung jawabkan dari hasil kerjanya tiap kelompok. 3) Selanjutnya guru melakukan diskusi kelompok besar untuk membandingkan serta mengkaji jawab yang tepat dan logis dari hasil kerja kelompoknya yang lain mengetahui bagaimana jawaban yang benar dari hasil kerja kelompoknya.

Ketiga, 1) Guru memberikan tugas tindak lanjut kepada kelompok yang hasil dari kerja kelompoknya ditemukan kesalahan di dalam menulis teks eksplanasi yang bertema "Bencana Alam". 2) Teks eksplanasi dibuat memperhatikan struktur dan kaidah kebahasaannya di dalam eksplanasi.3) Guru menilai apakah di dalam menulis teks eksplanasi ditemukan cara menulis kalimat atau isinya yang tidak melihatkan kelogisannya. 4) Guru menilai apakah ada ditemukan makna kosakata baru pada tulisan teks eksplanasi yang ditulis siswa. 5) Guru menilai dari cara kesalahan dari penggunaan tata bahasa ketika menulis teks eksplanasi. Seperti penggunaan tanda baca.

Pada pertemuan kedua dikelas eksperimen II, diberikan tes berupa unjuk kerja menuliskan teks eksplanasi dengan tema "Permasalahan Sosial", lalu hasil kerja siswa dikumpulkan dan diperiksa berdasarkan indikator yang dinilai.

Setelah data dikumpulkan maka dilanjutkan dengan teknik analisis data yang dimulai dari penskoran, penilaian serta melakukan uji analisis data terdiri dari normalitas, homogenitas,dan hipotesis.

\section{HASIL DAN PEMBAHASAN}

Penelitian dilaksanakan ditanggal 22Agustus - 02 September 2020 disekolah. Eksperimen I dilakukan/dilaksanakan pada tanggal 22 Agustus 2020. Eksperimen II dilakukan pada tanggal 27 Agustus 2020. Sampel penelitian yaitu siswa kelas XI SMA I Gunung Tuleh yang terdaftar tahun 2020/2021 berjumlah 50 orang. Hasil dan pembahasan dapat dilihat sebagai berikut ini. 
1. Keterampilan Menulis Teks Eksplanasi Siswa Kelas XI SMA N I Gunung Tuleh Menggunakan Model Think Talk Write (TTW).

Hasil daripada penelitian dijabarkan keterampilan teks eksplanasi menggunakan (TTW) yaitu, diperolehlah nilai 46,67/1 orang, 53,33/4orang, 60/7orang, 66,67/ 7orang, 73,33/4orang, 80/1 orang.

Tabel1. Distribusi Frekuensi Keterampilan Menulis Teks Eksplanasi Menggunakan Model Think Talk Write (TTW) Siswa Kelas XI SMA N I Gunung Tuleh

\begin{tabular}{cccc}
\hline No & X & F & FX \\
\hline 1 & 46,67 & 1 & 46,67 \\
2 & 53,33 & 4 & 213,32 \\
3 & 60 & 7 & 420 \\
4 & 66,67 & 7 & 466,69 \\
5 & 73,33 & 4 & 293,32 \\
6 & 80 & 1 & 80 \\
\hline \multicolumn{5}{c}{ Jumlah } & 24 & 1520 \\
\hline &
\end{tabular}

Berdasarkan data diatas diperoleh (M) sebesar 63,33 berada pada tingkat penguasaan $56-65 \%$ berkualifikas cukup (C).
2. Keterampilan Menulis Teks Eksplanasi Menggunakan Model Scramble Siswa Kelas XI SMA N I Gunung Tuleh).

Dari hasil penelitian maka dapat dijabarkan nilai keterampilan teks eksplanasi menggunakan Scramble yaitu, mendapatkan nilai 53,33/4orang, 60/2orang, 66,67/5orang, 73,33/7orang, 80/5orang, 86,67 3/orang.

Tabel2. Distribusi Frekuensi Keterampilan Menulis Teks Eksplanasi Menggunakan Model Scramble Siswa Kelas XI SMA N 1 Gunung Tuleh

\begin{tabular}{|c|c|c|c|}
\hline No & $\mathrm{X}$ & $F$ & FX \\
\hline 1 & 53,33 & 4 & 213,32 \\
\hline 2 & 60 & 2 & 120 \\
\hline 3 & 66,67 & 5 & 333,35 \\
\hline 4 & 73,33 & 7 & 513,31 \\
\hline 5 & 80 & 5 & 400 \\
\hline 6 & 86,67 & 3 & 260,01 \\
\hline & Jumlah & 26 & 1839,99 \\
\hline
\end{tabular}

diperoleh rata-rata hitung 70,76berada pada tingkat penguasaan $66-75 \%$ yaitu baik Lebih Dari Cukup (LDC).

3. Perbandingan Model Think Talk Write (TTW) Model Scramble Terhadap Keterampilan Menulis Teks Explanasi Siswa Kelas X1 SMA N 1 Gunung Tuleh. 
Perbandingan yang siginifikan peserta didik//siswa yang ada penggunaan ke2 model karena disekolah.

$t_{\text {hitung }}>\mathrm{t}_{\text {tabel }} \quad(3,30>1,67), \quad$ hipotesis $\quad$ Sistematika dan alur dari alternatif diterima.

Berdasarkan hasil analisis nilai pembelajaran kooperatif ini dapat didesain guna mengaktifkan keterampilan menulis teks eksplanasi pesertadidik melalui inkuri (pencarian menggunakan model Scramble dalam sendiri) dan melalui pecakapan pembelajaran lebih baik dibanding (TTW). Hal ini terbukti dari nilai yang dikualifikasikan cukup (C) dengan nilai rata-rata 63,33 .

Dapat disimpulkan siswa kelas XI SMA N I Gunung Tuleh belum menguasai tentang teks eksplanasi. Penggunaan model Scramble sangat berpengaruh digunakan dalam proses pembelajaran, karena melalui model Scramble meningkatkan kemampuan menulis siswa. Hal ini dikarenakan perkelompok kecil yang berangotakan 4-5/ peserta didik (Abdullah, 2015:131).

Model pembelajaran Scramble itu dapat menciptakan rasa solidaritasnya sesama rekan kelompok mereka. Materi/bahanyang diberikan mengakibatkan berkesan serta diingatnya selalu oleh siswa. Model pembelajaran Scramble juga menjunjung siswa/i lebih kompetitif disertai memberikan melalui model Scramble dapat semangat/dukungan untuk bisa lebih meningkatkan minat siswa dalam terus maju, sehingga melalui penerapan belajar, karena model Scramble model Scramble ini dapat merupakan model yang inovatif meningkatkan keterampilan menulis sehingga dapat meningkatkan siswa. keterampilan siswa dalam menulis.

Hasil penelitian Ariska (2017)

Berdasarkan hasil penelitian "Perbandingan Model Pemebelajaran tersebut terlihat bahwa penggunaan Kooperatif Tipe Word Square dengan model Scramble lebih baik. TTW dan Tipe Scramble terhadap Hasil Belajar Scramble merupakan kooperatif, Biologi Kelas XI IPA Sma Negeri 16 pemanfaatan kelompok kecil diguna Bulukumba". Berdasarkan hasil analisis agar meningkatnya hasil belajar seluruh 
inferensial dilakukannya menggunakan uji-t

diperoleh nilai begitu signifikan antara sebesaran 0,039 yang melebih kecil didapat dibanding $\alpha \quad 0,05$ $(\operatorname{sign}<\alpha)$. Oleh sebab itu terdapatlah perbedaan signifikan hasil belajar yang diajar menggunakan model pembelajaran menggunkan Word Square dengan Scramble terhadap hasil belajar biologi peserta didik dikelas XI.IPA SMA Negeri16 Bulukumba.

\section{KESIMPULAN}

Berdasarkan hasil analisis data dan pembahasan diatas ditarik kesimpulannya bahwa ditemukan tiga hal berikut. Pertama, menggunakan model (TTW) memperoleh nilai 63,33 berada pada rentangan 56-65\% dengan kualifikasi yaitu cukup (C). Kedua, menggunakan model Scramble memperoleh nilai rata-rata 70,76 berada pada rentangan $66-75 \%$ dengan kualifikasi yaitu Lebih dari Cukup (LdC).

Ketiga, berdasarkan hasil uji-t terdapat perbandingan penggunaan (TTW) dengan model Scramble terhadap/kepada keahlian/keterampilan menulis eksplanasi siswa/i kelas XI
SMA N I Gunung Tuleh karena $t_{\text {hitung }}>t_{\text {tabel }}(2,33>1,67)$.

Jadi, dapat disimpulkan bahwa penggunaan model Scramble lebih baik digunakan untuk menaikan keahlian maupun keterampilan menulis teks eksplanasi siswa kelas XI SMA N I Gunung Tuleh.

\section{DAFTAR PUSTAKA}

Abdullah Sani, Ridwan. 2015. Pembelajaran Saintifik Untuk Implementasi. Kurikulum 2013. Bandung: Bumi Aksara.

Ariska, Nelly. 2017. "Perbandingan Model Pemebelajaran Kooperatif Tipe Word Square dengan Tipe Scramble erhadap Hasil Belajar Biologi Kelas XI IPA SMA Negeri 16 Bulukumba". Jurnal. Jurnal Biotek Volume 5Nomor 2.

Dalman. 2015. Keterampilan Menulis. Jakarta: PT Raja Grafindo Persada.

Huda, Muftahul. 2014. Model-model Pengajaran dan Pembelajaran. Yogyakarta: Pustaka Pembelajaran

Mulyadi, Yadi dkk. 2016. Intisari Tata Bahasa Indonesia. Bandung: YRAMA WIDIA.

Priyatni, Endah Tri. 2014. Desain Pembelajaran Bahasa Indonesia dalam Kurikulum 2013. Jakarta: PT Bumi Aksara.

Shoimin. 2016. 68 Model 
Pembelajaran Inovatif Dalam

Kurikulum 2013. Yogyakarta: ArRuzz Media.

Sugiyono. 2014. Metode Penelitian Kuantitatif dan Kualitatif dan $R \& D$. Bandung: Alfabeta, CV. 